JST 8 (1)(2019)
JURNAL SENI TARI
Tttp://iournal.unnes.ac.id/siu/index.php/ist

\title{
Tari Angguk Rodat sebagai Identitas Budaya Masyarakat Desa Seboto Kecamatan Ampel Kabupaten Boyolali
}

\section{Sri Utami ${ }^{1}$, Usrek Tani Utina ${ }^{2}$}

Jurusan Pendidikan Seni Drama Tari dan Musik, Fakultas Bahasa dan Seni, Universitas Negeri Semarang, Indonesia

\section{Info Artikel}

Sejarah Artikel

Diterima : 22 Mei 2019

Disetujui : 22 Juni 2019

Dipublikasikan : 23 Juli 2019

\section{Keywords:}

Angguk Rodat Dance;

identity; culture

\begin{abstract}
Abstrak
Penelitian ini bertujuan untuk mengetahui dan mendeskripsikan bentuk pertunjukan tari Angguk Rodat sebagai identitas budaya masyarakat Desa Seboto. Penelitian ini menggunakan metode kualitatif. Teknik pengumpulan data yang digunakan yaitu observasi, wawancara dan dokumentasi. Teknik analisis data penelitian ini menggunakan reduksi data, penyajian data dan penarikan kesimpulan.Hasil penelitian mengemukakan bahwa identitas budaya Desa Seboto melalui Tari Angguk Rodat dapat dilihat dari faktor biologis, sosial, kultural, religius, dan faktor ekonomi masyarakat Seboto. Pertunjukan Tari Angguk Rodat terdiri dari tema, pelaku, gerak, iringan, tata busana dan tata rias, tata pentas, pola lantai dan properti. Tari Angguk Rodat kini dapat dikenal masyarakat Seboto sebagai salah satu identitas kesenian Desa Seboto.

Abstract

This research aimed to find out and describe the forms of Angguk Rodat dance performances as the cultural identity of people in Seboto Village. This study used a qualitative method. Data collection techniques used observation, interview and documentation. The data analysis technique of this study used data reduction, data presentation and conclusion. The results of the study show that the cultural identity of Seboto Village through Angguk Rodat Dance includes some factors, such as the biological, social, cultural, religious, and economic aspects of the Seboto community. Angguk Rodat Dance Performance as a cultural identity of the Seboto community consists of themes, actors, movements, accompaniment, costume and make-up, stage performance, floor patterns and property. Therefore, Angguk Rodat Dance can be known by the Seboto community as one of the artistic identities of Seboto Village.
\end{abstract}

(c) 2019 Universitas Negeri Semarang

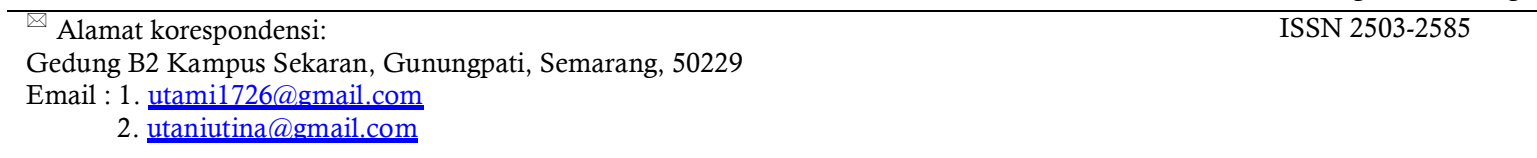




\section{PENDAHULUAN}

Tari tradisional adalah tari yang lahir, tumbuh, berkembang suatu masyarakat yang kemudian diturunkan atau diwariskan secara terus menerus dari generasi ke generasi, dengan kata lain, selama tarian tersebut masih sesuai dan di akui oleh masyarakat penduduknya termasuk tarian tradisional (Jazuli, 2008:72-72). Ditinjau dari segi artistiknya tari tradisional dapat dikategorikan menjadi tiga, yaitu 1) tari tradisional primitif, 2) tari tradisional rakyat, 3) tari tradisional istana (primitif). Tarian rakyat merupakan cermin ekspresi masyarakat (rakyat kebanyakan) yang hidup di luar tembok istana. Tarian rakyat banyak berpijak dari unsur-unsur budaya primitive, dapat dikatakan bahwa tarian rakyat merupakan perkembangan dari tarian primitif. Fungsinya adalah untuk melengkapi upacara dan hiburan.

Beberapa tarian yang masih ada di Kabupaten Boyolali yaitu Tari Topeng Ireng, Tari Kuda Lumping, Tari Jlantur, Dan Tari Angguk Rodat. Tari Angguk Rodat merupakan salah satu bentuk kesenian kerakyatan di Desa Seboto. "Angguk" berarti gerakan yang ditampilkan selalu mengangguk-angguk dan "rodat" berarti dalam pertunjukannya menggunakan alat musik rodat (bedug dan terbangan), jadi Tari Angguk Rodat merupakan tari yang setiap gerakannya menggunakan gerakan menganggukangguk dan diiringi dengan alat musik rodat (bedug dan terbangan).

Tarian ini sangat lekat dengan seorang laki-laki yang berbusana baju lengan panjang, celana di bawah lutut, kalung kace, kaos kaki, sabuk, sarung tangan, kacamata hitam, sandal bertali, rencong, slempang serta membawa properti kipas. Rencong merupakan sejenis mahkota. Rencong dalam Tari Angguk Rodat terbuat dari kain dan berbentuk segi tiga diujung terdapat satu bulu ayam berwarna kuning. Bagian bawah terdapat motif daun, bagian tengah terdapat manik-manik agar terlihat indah. Bentuk ikat kepala yang mengerucut dan menjulang ke atas memiliki makna "ke pada Tuhan", dimana masyarakat Seboto meyakini adanya satu Tuhan, yaitu Allah Subhanu Wataala.

Bentuk pertunjukan Angguk Rodat memadukan unsur tari dan vokal dengan 22 orang penari laki-laki dan 8 orang lakilaki sebagai pemusik. Instrument pengiring Tari Angguk Rodat yaitu beduk, terbangan, saron, demung, bende, drume, bass drume, gitar melodi dan keyboard. Suara instrumen musik yang digunakan dalam prtunjukan Tari Angguk Rodat terbilang unik dan khas yang memadukan suara alat musik Islami (bedug dan terbang), tradisional (saron, demung, bende, drume) dan modern (drume, bass drume, gitar melodi dan keyboard).

Tari Angguk Rodat memiliki dua unsur budaya yaitu Islam dan Jawa. Shalawat yang disajikan dengan vokal beserta alat musiknya yaitu bedug dan terbang yang dimainkan jelas menandakan bahwa unsur budaya Islam lekat dengan Tari Angguk Rodat.Namun ketika melihat pelafalan shalawat yang menyesuaikan karakteristik orang Jawa, menunjukan bahwa unsur jawa juga lekat dengan Tari Angguk Rodat.

Tari Angguk Rodat yang dikelola oleh Paguyuban Suko Budoyo dahulu merupakan Rodat biasa, kemudian dikembangkan agar tidak monoton atas pemikiran bapak Priyanto dan Sumadiyanto adiknya dengan menambah alat musik modern. Gerakan Tariannya juga mengikuti jaman, tidak monoton dan lebih berfariasi. Perubahan yang dilakukan oleh bapak Priyanto dan Sumadiyanto diperhatikan oleh Dinas Pariwisata dan Kebudayaan. Tari Angguk Rodat ditampilkan pada waktu 
hajatan, bersih desa, dan penyambutan Gubernur.

Penelitian terkait mengenai tari sebagai identitas pernah dilakukan oleh Sindara (2007) dalam skripsi berjudul "Tari Kretek Sebagai Tari Identitas Budaya Kabupaten Kudus Jawa Tengah". Hasil penelitian menunjukan bahwa tari Kretek merupakan tari identitas yang menggambarkan budaya Kabupaten Kudus di dalam unsurunsurnya terdapat beberapa yang mencirikan budaya di Kabupaten Kudus baik sebagai Kota Wali maupun sebagai penghasil rokok. Makna dalam tari Kretek meliputi gerak yang menggambarkan proses pembuatan rokok dari awal hingga akhir, busana dan aksesoris yang menggambarkan budaya Kudus serta tembang dalam iringan yang menceritakan keadaan Kota Kudus. Konsep penelitian Sindara terjadi juga pada konsep penelitian yang telah diteliti.

Berdasarkan latar belakang mengenai Tari Angguk Rodat, mendorong peneliti untuk mengetahui identitas budaya masyarakat Desa Seboto melalui Tari Angguk Rodat dan bentuk pertunjukan tari Angguk Rodat sebagai identitas budayaDesa Seboto.

\section{METODE}

Peneliti menggunakan pendekatan kualitatif dengan pendekatan sosiologi antropologi, dan pendekatan emik dan etik sebagai disiplin ilmu. Pendekatan sosiologi merupakan pendekatan berfokus pada lingkungan sekitar dan lingkungan tempat tinggal. Pendekatan antropologi merupakan sebuah disiplin ilmu yang mengkaji tentang manusia, baik dari segi budaya, perilaku, keanekaragaman dan sebagainya yang biasanya juga berhubungan dengan adat dan hasil-hasil karyanya (kebudayaan). Pendekatan antropologi digunakan peneliti untuk mengkaji mengenai karakteristik masyarakat (nilai dan norma, tradisi masyarakat Desa Seboto) yang berkaitan dengan Tari Angguk Rodat sebagai identitas budaya masyarakat Desa Seboto. Pendekatan emik adalah pengkategorian fenomena budaya menurut warga setempat (pemilik budaya) sedangkan etik adalah kategori menurut peneliti dengan mengacu pada konsep-konsep sebelumnya.

Pendekatan emik merupakan esensi yang fasih untuk fenomena kebudayaan pada suatu waktu tertentu. Pendekatan emik sebagai suatu usaha untuk mengungkapkan pola kebudayaan menurut persepsi pemilik budaya. Pendekatan emik menegaskan bahwa makna budaya dari "orang dalam (internal). Berbeda dengan pendekatan etik, penelitti "berdiri di luar" (eksternal) fenomena budaya (Kaplan dan Manners dalam Suwardi Endraswara, 2012). Pendekatan etik digunakan ketika dalam proses penyusunan penelitian dengan cara menjadikan konsep-konsep yang ada sebagai acuan dalam menyusun penelitian. Pendekatan emik digunakan ketika melakukan interaksi komunikasi yang di dalamnya terdapat symbolsimbol kepada pelaku pertunjukan dan masyarakat sekitar (pemilik budaya).

Observasi dilakukan secara langsung dengan mengamati proses latian dan pementasan Tari Angguk odat, serta aktivitas sosial masyarakat yang berkenaan dengan Tari Angguk Rodat.

Peneliti menggunakan jenis wawancara terstruktur. Narasumber penelitian adalah Bapak Priyanto sebagai ketua Paguyuban Suko Budoyo di Desa Seboto dan beberapa warga masyarakat. Wawancara dengan Bapak Priyanto mengenai gambaran secara spesifik tentang identitas budaya Desa Seboto melalui tari Angguk Rodat. Wawancara dengan masyarakat mengenai tanggapan terhadap Tari Angguk Rodat. 
Dokumentasi berupa foto-foto pertunjukan Tari Angguk Rodat, foto piagam penghargaan Paguyuban Suko Budoyo, data terkait kondisi geografis Desa seboto yang didapat dari kantor kelurahan Desa Seboto tahun 2018, dan notasi iringan Tari Angguk Rodat dari Iqro selaku orang yang berkecimpung di dunia musik tradisional. Selain data dari narasumber, peneliti menggunakan kamera handphone untuk mendokumentasikan proses latihan, jalannya pertunjukan, para pelaku, perlengkapan busana, dan alat-alat yang digunakan dalam pertunjukan Tari Angguk Rodat.

Teknik keabsahan data menggunakan teknik triangulasi sumber, teknik dan teori. Pengujian dan pengumpulan data dilakukan dengan sumber data primer dan sumber data sekunder yaitu Ketua Paguyuban Suko Budoyo, pelaku (pemain), dan masyarakat. Hasil wawancara dari berbagai sumber yaitu wawancara dengan Ketua Paguyuban Suko Budoyo, pelaku tari angguk rodat dan masyarakat dengan pertanyaan maupun jawaban yang sama dan berbeda dikategorikan dan disimpulkan sehingga mendapatkan data mengenai Tari Angguk Rodat sebagai identitas budaya masyarakat Desa Seboto.

Triangulasi teknik untuk menguji krediilitas data dilakukan dengan cara mengecek data kepada sumber yang sama dengan teknik yang berbeda. Peneliti mengaitkan teori yang digunakan dengan data pada penelitian yang dilakukan dan juga menggunakan triangulasi sumber. Penelitian ini menguji data tentang Tari Angguk Rodat sebagai identitas budaya masyarakat Desa Seboto. Pengujian dan pengumpulan data dilakukan dengan sumber data primer dan sumber data sekunder.

Cara mereduksi data dengan menggunakan pendekatan antropologi dilihat dari data yang diperoleh melalui observasi, wawancara dan dokumentasi mengenai karakteristik masyarakat (nilai dan norma, tradisi masyarakat Desa Seboto) yang berkaitan dengan Tari Angguk Rodat sebagai identitas budaya masyarakat Desa Seboto.

Data yang berupa sejarah Tari Angguk Rodat, latihan dan pementasan Tari Aangguk Rodat, prestasi yang diperoleh, bentuk pertunjukan Tari Angguk Rodat, dan respon masyarakat terhadap Paguyuban Suko Budoyo dideskripsikan secara detail.

Penarikan kesimpulan pada penelitian yang menggunakan pendekatan antropologi, emik dan etik yaitu peneliti menarik kesimpulan secara bertahap dan dapat menjawab permasalahan yang dirumuskan dengan memperhatikan perkembangan perolehan data. Data yang diperoleh dari lapangan melalui wawancara, observasi dan dokumentasi mengenai tari angguk rodat sebagai identitas budaya masyarakat Desa Seboto diolah kemudian direduksi, disajikan, dan disimpulkan datanya dari hasil penelitian di lapangan sehingga data yang diperoleh valid dan dapat dipertanggungjawabkan.

\section{HASIL DAN PEMBAHASAN}

Bentuk Pertunjukan Tari Angguk Rodat Bentuk pertunjukan Tari Angguk Rodat meliputi tema, pelaku, gerak, iringan, tata rias dan busana, pola lantai, tata cahaya, properti.

\section{Tema}

Identitas budaya masyarakat Desa Seboto tercermin dalam tema yang diangkat yaitu keagamaan. Tema keagamaan dibuktikan dengan adanya syair yang digunakan, seperti syair yang berjudul salam, syahadat, sholawat, tawasul I'badallah rijallah, ya hanna dan musholla lali ala rasul, syair tersebut diambilkan 
dari surat al-barzanzi. Tema keagamaan melambangkan kehidupan masyarakat Seboto dimana Tari Angguk Rodat selalu menonjolkan kebersamaan, kekeluargaan dan agama tidak menonjolkan ego, melainkan memahami makna-makna ajaran untuk menemukan titik kerukunan antara Tuhan dan agar terwujud kerukunan antar umat beragama.

Tari Angguk Rodat yang dikenal sebagai sebuah tarian yang sekarang berfungsi sebagai hiburan selalu menggambarkan kebersamaan dan kekeluargaan, kegembiraan serta segala keceriaan dalam setiap penampilannya. Jaman dahulu Tari Angguk Rodat digunakan sebagai media penyebaran agama Islam, namun seiring dengan perkembangan zaman Tari Angguk Rodat berubah fungsi menjadi sarana hiburan.

\section{Pelaku Tari Angguk Rodat}

Pelaku dalam pertunjukan Tari Angguk Rodat meliputi pelaksana acara, penari dan pemusik. Ketiga bagian ini akan melakukan pertunjukan dengan sebaik-baiknya.

Pelaksana acara pada pertunjukan tari angguk rodat menjadi suatu unsur yang harus dipersiapkan, karena tanpa adanya pelaksana acara atau tuan rumah maka pertunjukanpun tidak akan terlaksana. Tuan rumah dalam pertunjukan tari angguk rodat sesuai dengan aktivitas yang dilaksanakan, seperti acara bersih desa yang diadakan di Desa Seboto. Pelaksana acara dilakukan oleh masyarakat setempat. Masyarakat secara sukacita bergotong royong mempersiapkan segala sesuatu, mulai dari persiapan hingga akhri kegiatan.

Masyarakat sebagai tuan rumah menyiapkan segala kebutuhan yang diperlukan dalam pertunjukan tari angguk rodat, mulai dari perencanaan, pelaksanaan, hingga akhir dari acara.
Tahap perencanaan dilakukan dilakukan secara bermusyawarah oleh masyarakat yang bermusyawarah untuk mengatur persiapan mulai dari tempat pertunjukan, transportasi dan akomondasi, tamu yang diundang, pembawa acara, pengawas jalannya acara, serta segala sesuatu yang dibutuhkan dalam acara. Pelaksanaan sebagai persiapan sangat perting dilakukan, agar acara dapat terlaksana dengan baik dan tujuan dari acara dapat tercapai.

Tahap pelaksanaan semua yang terlibat dalam pelaksanaan harus sudah bersiap ditempat masing-masing dengan tugas dan tanggungjawab masing-masing, dan semua anggota harus berkomunikasi dengan baik untuk meminimalisir kesalahan. Tahap akhir merupakan pelepasan tamu yang diundang dengan menyatakan ucapan perpisahan dan salam hormat pada para tamu karena telah meluangkan waktu untuk menghadiri acara, setelah acara selesai seluruh anggota merapikan kembali tempat yang telah digunakan untuk acara tersebut.

Penari Angguk Rodat tidak memandang tua atau pun muda, dari umur 13 tahun hingga 70 tahun. Tari Angguk Rodat ada 22 orang penari lakilaki yang diantaranya 1 penari SMP, 1 orang penari mahasiswa, 4 orang penari bekerja sebagai wiraswasta, dan 18 penari bekerja sebagai petani. Selain menyesuaikan dengan acara dan panggung, jumlah penari yang banyak membuat tarian lebih semarak dan menarik untuk dinikmati, seperti pada penamplannya di acara bersih desa di Desa Seboto pada tanggal 15 September 2018 (wawancara Priyanto, 14 September 2018)

Pemain musik Tari Angguk Rodat biasanya berasal dari masyarakat Desa Seboto yang senang akan kesenian, bahkan diantara mereka merupakan turunan dari orang tuannya. Pemusik 
dalam Tari Angguk Rodat pada umumnya tidak mengenal notasi musik, mereka biasa memainkan alat musik secara otodidak. Mereka mengandalkan indera pendengaran dan mengasah kepekaan rasa terhadap musik yang mereka mainkan. Pemain musik Tari Angguk Rodat terdiri dari 8 orang diantaranya penyanyi lagu sekaligus pemain drum Tari Angguk Rodat 1 orang, pemain terbangan sekaligus pemain saron 4 orang, pemain bass 1 orang, pemain keyboard 2 orang (wawancara Priyanto, 14 September 2018).

\section{Gerak Tari Angguk Rodat}

Gerak pada Tari Angguk Rodat ada dua, yaitu gerak murni dan gerak maknawi. Gerak murni pada Tari Angguk Rodat seperti gerak meloncat, gerak mengangkat kaki dan mengayunkan tangan yang tidak memiliki makna tertentu dan hanya mengutamakan keindahan geraknya saja. Gerak maknawi dalam Tari Angguk Rodat yaitu:

\section{Gerak Jalan Membungkuk}

Gerak jalan membungkuk dilakukan dengan jalan posisi badan membungkuk seperti waktu rukuk pada shalat dengan posisi keduan tangan memegang kipas kemudian diayunkan ke atas dan ke bawah. Gerakan kaki berjalan sambil diikuti anggukan kepala. Gerakan tersebut memiliki makna bahwa manusia khususnya masyarakat Seboto harus saling menghormati, selalu rendah hati dan patuh kepada agamanya. Gerak jalan membungkuk merupakan gerakan khas Tari Angguk Rodat.

\section{Gerak Menengadahkan Kedua Tangan}

Gerak menengadahkan kedua tangan yaitu dilakukan dengan kedua tangan menghadap ke atas seperti pada saat berdoa. Gerakan menengadahkan ke dua tangan memiliki arti yaitu masyarakat Seboto mengangkat tangan ketika sedang berdoa dan sudah menjadi hal yang disyariatkan dalam Islam. Perbuatan ini merupakan salah satu adab dalam berdoa dan juga nilai tambah yang mendukung terkabulnya doa.

\section{Angguk-Angguk Kepala}

Gerakan angguk-angguk kepala yaitu dilakukan dengan kepala menaikturunkan kepala diikuti dengan kaki berjalan dan ayunan ke dua kipas. Gerakan angguk-angguk kepala memiliki arti yaitu masyarakat Seboto yang menyatakan persetujuan dan menerima ajaran agama Islam yang telah di ajarkan oleh Sunan Kali Jaga.

Tari Angguk Rodat sebagai tari rakyat, tentu tidak semua ragam gerak memiliki nama-nama khusus. Para pelaku Tari Angguk Rodat biasa memberi nama ragam gerak dengan urutan, yaitu: 1) ayun-ayun kipas, 2) laku nundhuk, 3) lompat ayun kipas, 4) laku telu, 5) laku nundhuk (2), 6) laku telu(2), 7) ayun-ayun kipas (2), 8) langkah ayun kipas, 9) angguk-angguk, 10) muslaku mundur 11) langkah ayun kipas (2). Penamaan ragam gerak sesuai dengan urutan syair lagu mempermudah bagi penari Tari Angguk Rodat untuk menghafalkan urutan gerak. Peneliti telah mewawancarai semua pelaku pertunjukan Tari Angguk Rodat dan seluruhnya mengatakan bawa tidak mengetahui nama-nama ragam gerak pada Tari Angguk Rodat. Pelaku Tari Angguk Rodat menyebut ragam gerak sesuai dengan judul syair yang bertujuan untuk memudahkan dalam menghafal ragam gerak Tari Angguk Rodat.

\section{Iringan Tari Angguk Rodat}

Suara instrumen dari alat musiknya adalah perpaduan antara alat musik islami (begud, terbangan), gamelan jawa (saron, demung, bende), dan alat musik modern (drume, gitar melody, keyboard). Dahulu hanya menggunakan terbangan, 
pada saat sekarang telah bertambah alat musik yang digunakan untuk mengiringi (wawancara Priyanto, 14 September 2018).

Sejarah perkembangan penggunaan alat musik dari yang awalnya hanya menggunakan bedug dan terbangan hingga penambahan alat musik tradisional dan modern dimualai tahun 1911-2009. Tahun 1911-2008 Tari Angguk Rodat hanya menggunakan alat musik bedug dan terbangan, hal tersebut terjadi karena belum ada pengaruh kebudayaan modern masuk di Desa Seboto. Tahun 2009 seniman Desa Seboto yaitu Bapak Priyanto memiliki ide atau gagasan untuk mengembangkan kesenian Tari Angguk Rodat agar jaya dan tidak punah. Bapak Priyanto menambahkan alat musik tradisional (saron,demung, bende) dan modern (drum, bass drum, gitar melody dan keyboard) untuk menjadikan Tari Angguk Rodat lebih diminati dan menarik untuk dipertunjukkan tanpa mengurangi tujuan pertunjukkan Tari Angguk Rodat yaitu menyampaikan ajaran-ajaran baik.

Bentuk identitas budaya masyarakat Seboto terlihat pada penggunaan alat musik bedug dan rebana. Bedug berfungsi untuk mengundang atau memberi tahu ke pada penduduk Seboto bahwa sudah waktunya untuk melaksanakan shalat. Fung bedug yang lain yaitu untuk memeriahkan hari besar Islam, seperti memainkan bedug saat mengumandangkan takbir saat hari raya idul fitri dan idul adha, kemudian penggunaan alat musik terbangan menggambarkan masyarakat Seboto yang masih melestarikan kesenian qasidah dan hadroh. Penggunaan alat musik terbangan bertujuan agar alat musik terbangan tetap lestari dan sejalan dengan perkembangan jaman. Suara instrument dari alat musik dalam Tari Angguk Rodat tidak memiliki makna khusus, kehadirannya hanya sebagai pengatur irama, menciptakan suasana dan memberikan penekanan pada gerak-gerak tertentu.

\section{Tata Rias dan Busana Tari Angguk Rodat}

Tata rias wajah pada Tari Angguk Rodat adalah rias korektif. Tata rias korektif adalah tata rias wajah yang menyerupakan dan mengubah penampilan fisik yang dinilai kurang sempurna. Tari Angguk Rodat menggunakan rias korektif karena untuk menarik penonton dan wajah penari tidak terlihat polos. Bahan-bahan rias wajah digunakan bersama-sama (wawancara dengan Priyanto, 14 September 2018).

Rrias wajah dalam Tari Angguk Rodat yang memerlukan beberapa tahap seperti langkah pertama menggunakan alas bedak atau foundation.Setelah menggunakan alas bedak atau foundation memakai bedak tabur pada wajah. Bagian alis menggunakan pensil alis berwarna hitam. Bagian bibir menggunakan lipstick warna merah agar terlihat menarik. Garis bagian dahi dan dagu menggunkaan pensil alis berwarna hitam (wawancara degan Priyanto, 14 September 2018).

Penggunaan rias pada Tari Angguk Rodat menggunakan warna-warna terang seperti merah dan hitam menggambarkan masyarakat Seboto yang ceria, berani dan kuat, seperti berani dalam mengambil keputusan dikehidupan sehari-hari, dalam kondisi kemiringan tanah yang curam dan landau, keadaan yang sunyi pada malam hari menjadikan masyarakat Seboto memiliki kepribadian yang pemberani. Karakteristik masyarakat Seboto yang sederhana tercermin dalam kehidupan sehari-hari yang tertuang dalam penggunaaan bahan make up yang menggunakan merk-merk yang berstandar dengan harga yang lebih murah.

Tata rias rambut yang digunakan dalam Tari Angguk Rodat sangatlah sederhana yaitu menggunakan iket kepala/rencong hasil kreasi Bapak 
Priyanto.Aksesoris ikat kepala/rencong yang digunakan dalam tata rias rambut penari Tari Angguk Rodat. Rencong adalah sejenis mahkota. Rencong dalam Tari Angguk Rodat terbuat dari kain dan berbentuk segi tiga diujung terdapat satu bulu ayam berwarna kuning. Bagian bawah terdapat motif daun, bagian tengah terdapat manik-manik agar terlihat indah. Bentuk ikat kepala yang mengerucut dan menjulang keatas memiliki makna "yakin kepada Tuhan", dimana masyarakat Seboto meyakini adanya satu Tuhan, yaitu Allah Subhanu Wataala.

\section{Tata Busana Tari Angguk Rodat}

Busana Tari Angguk Rodat awalnya hanya menggunakan celana hitam dibawah lutut dan baju putih lengan panjang. Perkembangan busana tari telah disesuaikan dengan tema Tari Angguk Rodat. Tata busana Tari Angguk Rodat tertutup, maksud dari tertutup yaitu panjang menutup aurat yaitu dengan dikenakannya baju lengan panjang, celana di bawah lutut, selain untuk menutup aurat juga bertujuan untuk menghangatkan badan, dimana keseharian masyarakat Seboto mengenakan baju berlengan panjang dan tebal, karena daerah Seboto merupakan daerah pegunungan, seperti yang dikatakan Bapak Priyanto berikut.Tari Angguk Rodat dalam kostumnya menggunakan baju lengan panjang, celana dibawah lutut, kalung kace, kaos kaki, sabuk, sarung tangan, kaca mata hitam, sandal bertali, jamang dan slempang.

\section{Pola Lantai Tari Angguk Rodat}

Pola lantai adalah garis yang di lalui dan di bentuk oleh penari di panggung. Pola lantai berfungsi untuk membuat posisi dalam sebuah ruang gerak. Pola lantai yang di gunakan Tari Angguk Rodat sederhana dan hanya bermain level untuk menambah menarik gerakannya, pola lantai yang ada yaitu pola lantai garis lurus dan pola lantai garis lengkung (wawancara dengan Priyanto, 14 September 2018). Makna simbolik pola lantai pada Tari Angguk Rodat yaitu:

\section{Pola Lantai Garis Lengkung}

Pola lantai garis lengkung yaitu banyak digunakan pada tari rakyat karena hubungannya dengan magis atau keagamaan. Pola lantai melingkar pada Tari Angguk Rodat dilakukan saat salah satu penari melakukan gerak atraksi dan penari lain membentuk lingkaran kecil dibawahnya. Pola lantai melingkar memiliki makna bahwa masyarakat Seboto beranggapan bahwa setiap langkah dalam menjalani kehidupan di dunia pasti akan diperhitungkan diakhirat. Ketika hidup di dunia berbuat suatu keburukan makan diakhirat akan mendapat balasan dari Allah Subhanahu Wataala. Pola lantai melingkar digunakan pada gerak atraksi.

\section{Pola Lantai Garis Lurus}

Pola lantai garis lurus menampilkan kesan sederhana tapi kuat, seperti salah satu ciri tari rakyat yaitu sederhana. Tari Angguk Rodat sebagai jenis tari rakyat bersifat sederhana namun makna yang terkandung dari isi tariannya sangat berguna bagi manusia. Salah satu pola lantai garis lurus pada Tari Angguk Rodat berbanjar yang menyimbolkan shaf ketika shalat. Pola lantai berbanjar memiliki makna bahwa masyarakat Seboto meyakini bahwa umat muslim dianjurkan Rasulallah saw untuk meluruskan shaf shalatnya. Pola lantai berbanjar digunakan pada saat ragam gerak ayun-ayun kipas.

\section{Tata Suara Tari Angguk Rodat}

Saat peneliti melakukan pengamatan, Tari Angguk Rodat menggunakan Sound system dan speaker yang memiliki volume suara yang cukup besar agar iringan musik terdengar oleh 
penari dan penonton. Berikut tata suara yang digunakan dalam pertunjukan Tari Angguk Rodat.

\section{Tata Pentas Tari Angguk Rodat}

Tari Angguk Rodat dipentaskan di tempat terbuka seperti halaman rumah, hal ini erat kaitannya dengan fungsi tari angguk rodat sebagai media dakwah agama Islam. Pertunjukan Tari Angguk Rodat biasanya dipentaskan di halaman rumah yang berukuran lebar 10 meter dan panjang 16 meter dengan tatanan panggung yang sederhana. Bagian pembatas penonton dengan panggung penari Tari Angguk Rodat dibatasi dengan pagar bambu yang mengelilingi panggung mebentuk setengah lingkaran seperti yang terlihat pada acara sedekah bumi di Desa Seboto Desa Seboto

Identitas budaya masyarakat Seboto melalui tari angguk rodat tercermin pada penggunaan panggung. Panggung yang digunakan untuk pertunjukan tari angguk rodat di tempat terbuka seperti halaman rumah yang luasnya 9x11 meter. Panggung yang luas dan membentuk setengah lingkaran menandakan masyarakat pedesaan khususnya Desa Seboto yang guyub rukun dan hidup secara berkelompok. Pemilihan tempat yang luas untuk memenuhi jumlah penari yang banyak yaitu 22 orang penari lakilaki dan menggunakan volume gerak yang besar.

\section{Tata Lampu Tari Angguk Rodat}

Tata lampu dalam pertunjukan Tari Angguk Rodat dapat digunakan di tempat pentas baik itu pada malam hari maupun siang hari. Pencahayaan yang digunakan pada saat pertunjukan malam hari menggunakan lampu halogen $500 \mathrm{w}$ berjumlah 4 buah lampu yang di pasang di atas panggung sebelah kanan, tengah, dan kiri yang di pasang di tiang bambu dan 1 buah lampu bohlam diletakkan di tengahtengah panggung pemusik. Pementasan pada siang hari atau sore hari cukup menggunakan pencahayaan dari sinar matahari (wawancara dengan Priyanto, 14 September 2018).

\section{Properti Tari Angguk Rodat}

Tari Angguk Rodat dalam pementasannya menggunakan properti. Properti yaitu kelengkapan yang digunakan dalam tari. Properti ini digunakan pada saat menari dan digunakan untuk memperindah suatu gerakan. Pengaruh identitas budaya masyarakat Seboto terlihat pada penggunaan properti. Properti yang digunakan yaitu dua buah kipas yang terbuat dari bambu yang ditempeli dengan hiasan kain. Properti yang digunakan merupakan identitas dari Tari Angguk Rodat di Desa Seboto karena memanfaatkan kreatifitas masyarakat Seboto yang memiliki keahlian kerajinan tangan dalam bentuk anyaman bambu, seperti kukusan dan tumbu. Masyarkat Seboto memanfaatkan pohon bambu yang ada disekeliling rumah kemudian dirangkai hingga menjadi kipas. Properti digunakan untuk memperindah gerakan pada Tari Angguk Rodat. Properti yang digunakan dalam pertunjukan Tari Angguk Rodat terbuat dari bambu dan dilapisi kain bermotif bunga yang di bagian ujung bawah dan atas dihiasi untaian benang agar terlihat indah. Properti digunakan untuk mempercantik suatu gerak.

Pemilihan warna pada kipas melambangkan kebiasaan masyarakat Seboto, seperti warna yang melambangkan kekuatan dan keberanian, dimana pada masyarakat pegunungan identik memiliki kekuatan dan energi yang kuat. Warna merah juga memberikan nuansa yang semangat dan menjadi pusat perhatian. Warna selanjutnya yaitu warna putih, warna putih identik dengan kesucian, kesederhanaan dan kebersihan. Pemilihan warna putih bertujuan untuk terpelihara dari hal-hal yang buruk. Warna terakhir pada properti kipas yaitu 
warna kuning. Warna kuning mengandung makna optimis, semangat dan ceria. Warna kuning melambangkan masyarakat pegunungan khususnya masyarakat Seboto yang sumeh atau tidak sombong, mempunyai semangat yang tinggi, seperti semangat dalam bertani, sehingga dengan semangat yang tinggi dapat menuai panen yang memuaskan.

\section{Identitas Budaya Masyarakat Desa Seboto}

Bentuk identitas budaya masyarakat Desa Seboto dapat dilihat pada aspek biologis, social, kultural, religious, dan ekonomi masyarakat Desa Seboto. Biologis dimana faktor biologis yang termasuk didalamnya yaitu faktor keturunan atau genetis.

\section{Aspek Biologis}

Faktor biologis yang termasuk didalamnya faktor keturunan atau genetis. Bakat merupakan faktor bawaan dan pengaruh lingkungan. Jadi apabila seseorang yang terlahir dengan suatu bakat khusus, jika dididik dan dilatih maka ketika remaja bakat itu akan berkembang dan dimanfaatkan secara optimal. Sebaliknya jika dibiarkan saja tanpa pengarahan dan penguatan, bakat itu akan mati dan tak berguna. Hal ini terjadi pada masyarakat Seboto dimana terdapat jenis bakat khusus yaitu bakat kreatif dan produktif. Dimana masyarakat Seboto mampu menciptakan sesuatu yang baru contohnya dalam hal pertunjukan Tari Angguk Rodat, dengan merekonstruksinya menjadi pertunjukan yang menarik, terlihat pada kostum yang meriah dengan pemilihan warna yang cerah seperti merah, hijau, kuning, putih.

Tari Angguk Rodat identik dengan penggunaan properti yaitu dua buah kipas yang ditempeli dengan kain dengan menggunakan warna merah, putih, dan kuning. Pemilihan warna pada kipas melambangkan kebiasaan masyarakat Seboto, seperti warna yang melambangkan kekuatan dan keberanian, dimana pada masyarakat pegunungan identik memiliki kekuatan dan energi yang kuat. Warna merah juga memberikan nuansa yang semangat dan menjadi pusat perhatian. Warna selanjutnya yaitu warna putih, warna putih identik dengan kesucian, kesederhanaan dan kebersihan. Pemilihan warna putih bertujuan untuk terpelihara dari hal-hal yang buruk. Warna terakhir pada properti kipas yaitu warna kuning. Warna kuning mengandung makna optimis, semangat dan ceria. Warna kuning melambangkan masyarakat pegunungan khususnya masyarakat Seboto yang sumeh atau tidak sombong, mempunyai semangat yang tinggi, seperti semangat dalam bertani, sehingga dengan semangat yang tinggi dapat menuai panen yang memuaskan dan memadukan alat musik tradisional, islami dan modern sehingga menciptakan suasana yang meriah. Faktor yang mempengaruhi perkembangan yang dimiliki masyarakat Seboto yaitu kesempatan khusus untuk mengembangkan diri, dukungan dan dorongan dari orang terdekat, sarana dan prasarana yang memadai, dan pola asuh orang tua.

\section{Sosial}

Bentuk umum proses sosial merupakan interaksi sosial yang juga dapat dinamakan proses sosial karena interaksi sosial merupakan syarat utama terjadinya aktivitas-aktivitas sosial. Interaksi sosial merupakan hubunganhubungan sosial yang dinamis menyangkut hubungan antara orangorang perorangan, antara kelompokkelompok manusia, maupun antara orang perorangan dengan kelompok manusia. Apabila dua orang bertemu, interaksi dimulai pada saat itu. Mereka saling menegur, berjabat tangan, saling berbicara atau bahkan mungkin 
berkelahi. Masyarakat yang hidup dengan bayang-bayang bencana erupsi Gunung Merapi dan Gunung Merbabu menciptakan kebudayaan dan tradisi dalam kehidupan mereka. Bencana yang terjadi menjadikan penduduknya untuk tidak hidup secara individual. Mereka harus menjunjung tinggi nilai solidaritas sosial karena hal tersebut akan membantu ketika terjadi bencana yang mengharuskan mereka untuk saling tolong-menolong (wawancara dengan Suparman 20 September 2018).

Solidaritas tersebut dibangun dengan berbagai cara melalui budaya. Masyarakat membudayakan pertemuanpertemuan rutin melalui berbagai bentuk yang berbeda. Pertemuan yang dilaksanakan, diantaranya pertemuan rutin $\mathrm{RT}$ dan $\mathrm{RW}$, arisan, dan pertemuan keluarga. Desa Seboto selain melakukan pertemuan RT dan RW, arisan, dan pertemuan keluarga juga terdapat pertemuan sosial warga masyarakat untuk menjalin kebersamaan yang telah dilaksanakan secara turun-temurun untuk selalu dilaksanakan. Pertemuan sosial tersebut yaitu berupa upacara tradisi bersih desa yang dilaksanakan satu tahun sekali dan melakukan aktivitas seni pertunjukan baik latihan atau pun pementasan.

Bagi masyarakat Desa Seboto melakukan pertemuan itu penting, misalnya dalam pertemuan RT yang berguna untuk menguatkan kerukunan antar lingkungan tetangga, kemudian dalam pertemuan RW mempunyai tujuan untuk meningkatkan kerukunan antar warga masyarakat Desa Seboto. Pertemuan arisan bertujuan untuk meningkatkan perekonomian warga masyarakat Desa Seboto. Pertemuan bersih desa sendiri bertujuan untuk menjaga kebersihan Desa Seboto dan menjaga kebudayaan yang ditinggalkan oleh para pendahulu Desa Seboto yang dilaksanakan secara terus menerus setiap satu tahun sekali. Sedangkan pertemuan kegiatan berjanjen dilakukan secara berkeliling dalam bentuk membaca ayatayat al-barzanzi secara bersama-sama dan bergantian dari rumah ke rumah yang dilaksanakan satu seminggu sekali. Kegiatan tersebut untuk menumbuhkan solidaritas sosial.

\section{Faktor Kultural}

Kultural merupakan aktivitas manusia yang berhungan dengan budaya. Aktivitas yang dimaksud adalah wujud kebudayaan sebagai suatu tindakan berpola dari manusia dalam masyarakat itu. Wujud ini sering pula disebut dengan sistem sosial. Sistem sosial ini terdiri dari aktivitas-aktivitas manusia yang saling berinteraksi, mengadakan kontak, serta bergaul dengan manusia lainnya menurut pola-pola tertentu yang berdasarkan adat tata kelakuan, sifatnya konkret, terjadi dalam kehidupan sehari-hari, dan dapat diamati dan didokumentasikan. Penduduk Seboto $90 \%$ bekerja disektor pertanian khususnya petani sayur, tembakau dan cengkih.

Sehari-hari penduduk yang bekerja di sektor pertanian berangkat pagi menuju ladang dan pulang sebelum azan zuhur, kemudian berangkat keladang lagi dan pulang disore hari. Selain kegiatan bertani penduduk Seboto juga melakukan kegiatan keagamaan yang sudah turun temurun dilakukan, yaitu perjanjen yang dilakukan secara bergantian dari rumah ke rumah warga. Kegiatan perjanjen dilakukan setelah shalat magrib dan dilakukan satu minggu sekali. Adanya aktivitas penduduk Seboto yang saling berinteraksi pada kegiatan perjanjen merupakan dasar gagasan Bapak Priyanto untuk menjadikan Tari Angguk Rodat semakin berkembang dan dikenal.

Kegiatan perjanjen keliling masyarakat Seboto yang laksanakan setiap satu minggu sekali setelah shalat magrib. Kegiatan perjanjen tidak 
memandang tua ataupun muda, namun dari anak-anak hingga dewasa. Kegiatan perjanjen keliling menjadikan dasar terbentuknya perkembangan Tari Angguk Rodat. Syair yang terdapat dalam surat al-barzanji digunakan dalam Tari Angguk Rodat.

Bapak Priyanto selaku ketua paguyuan Suko Budoyo setiap satu minggu sekali mengadakan latihan bersamauntuk mewujudkan Tari Angguk Rodat semakin berkembang, Bapak Priyanto mengadakan pertemuan kelompok paguyuban Suko Budoyo satu minggu sekali. Pertemuan tersebut membahas tentang cara yang harus dilakukan untuk mewujudkan kesenian tersebut lebih terlihat menarik pada saat dipertunjukkan, selain tujuan tersebut Bapak Priyanto berharap agar Tari Angguk Rodat tetap lestari dan lamakelamaan tidak luntur.

\section{Faktor Keagamaan Masyarakat Desa Seboto}

Keagamaan adalah sistem yang mengatur tata keimanan (kepercayaan) dan kepribadian kepada Tuhan Yang Mahakuasa serta tata kaidah yang berhubungan dengan pergaulan manusia dan manusia serta lingkungannya. Dimana masyarakat Seboto meyakini adanya satu Tuhan, yaitu Allah Subhanu Wataala yang tercermin pada bentuk ikat kepala yang mengerucut dan menjulang keatas memiliki makna "ke pada Tuhan",

Agama dan kebudayaan merupakan dua hal yang berdekatan dengan masyarakat. Bahkan banyak yang salah mengartikan bahwa agama dan kebudayaan mempunyai kedudukan masing-masing dan tidak dapat disatukan, karena agamalah yang mempunyai kedudukan tertinggi dari kebudayaan. Namun, keduanya memiliki hubungan yang erat dalam kehidupan masyarakat. Masyarakat Desa Seboto sebagian besar beragama Islam, maka tak heran jika kesenian yang lahir di desa tersebut bernuansa Islam. Seperti halnya Tari Angguk Rodat, terlihat dari syairsyair yang dilantunkan, syair tersebut diambil dari kitab Al-Barjanji, dimana pada masyarakat terdahulu yang melakukan kegiatan barjanji keliling dan masih dilestarikan hingga sekarang.

Tari Angguk Rodat merupakan salah satu kesenian sholawat yang bernafasan Islam yang berada di Lereng Gunung Merbabu, tepatnya di Desa Seboto Kecamatan Ampel Kabupaten Boyolali. Tari Angguk Rodat tidak diketahui secara pasti mulai kapan kesenian ini ada dan oleh siapa kesenian ini diciptakan. Meski tidak dapat dipastikan keberadaannya, namun menurut ketua paguyuban Suko Budoyo sejak tahun 1911 Tari Angguk Rodat sudah ada.

Gagasan dalam seni Tari Angguk Rodat yaitu pada zaman para wali salah satu wali adalah Makdum Ibrahim yang lebih dikenal dengan sebutan Sunan Bonang. Beliau mengangkat murid jejaka dari Tuban yaitu Jaka Setya atau Raden Sahid. Sebagai ujian dalam mencapai ilmunya untuk menunggu tongkat di dekat sungai selama sembilan tahun dan akhirnya diangkat menjadi murid dengan gelar Sunan Kalijaga, dan diutus untuk menyebarkan agama Islam di tanah Jawa. Sunan Kali Jaga dalam penyebaran agamanya tidak merubah budaya-budaya yang sudah ada, adat-istiadat yang sudah ada bahkan seni-seni yang ada pada zaman kerajaan majapahit, dalam penyebaran ilmunya sampai kepolosokpelosok kampung dengan seni-seni yang ada pada zaman itu, salah satunya adalah seni tari rodat yang berarti (weruha kalimat syahadad), untuk menarik perhatian pnduduk Seboto, Sunan Kalijaga menggunakan media tari yaitu Tari Angguk Rodat, dengan media tari tersebut, maka para penduduk kampung berbondong-bendong mendatangi seni 
rodat. Disela-sela pertunjukan, Sunan Kalijaga mengajarkan syariat-syariat islam dan mengenalkan syahadat, dengan sepontan penduduk mengangguk-angguk dengan membaca dua kalimat syahadad (asyhadu alla illah hailla wa wa asyhadu anna muhammadar rosulullah). Saat zaman para wali banyak yang menamakan seni tersebut dengan sebutan seni rodat atau seni tari angguk (wawancara dengan Priyanto, 14 September 2018).

Setelah adanya ajaran agama Islam dari Sunan Kalijaga, penduduk Seboto sering melakukan kegiatan keagamaan yaitu perjanjen killing. Kegiatan perjanjen lambat laun menjadikan sebuah kebiasaan atau adat di Desa Seboto. Tahun 2009 salah satu seniman dari Desa Seboto yaitu Bapak Priyanto memiliki ide atau gagasan untuk mengembangkan seni Tari Angguk Rodat agar tidak monoton untuk dipertunjukkan namun tidak menghilangkan keasliannya yaitu gerakan yang mengangguk-angguk. Perkembangan mengacu pada kebiasaan masyarakat Seboto yang sering melakukan kegiatan perjanjen keliling, kemudian syair yang ada di surat albarzanji diambil kemudian digunakan sebagai syair pada Tari Angguk Rodat. Bapak Prityanto juga menambahkan alat musik modern seperti gitar, bass, drum dan melody. Kostum yang dikenakan juga lebih menarik dengan menggunakan warna-warna yang mencolok seperti warna merah, kuning, hijau dan putih. Gerak yang digunakan juga semakin bervariasi seperti gerakan yang energik yang menandakan penduduk pegunungan yang berfisik kuat (wawancara dengan Priyanto, 14 September 2018).

\section{Perekonomian Masyarakat Desa Seboto} Mata pencaharian Desa Seboto adalah bertani (sayur, tembakau dan cengkih), Masyarakat Seboto mengandalkan lahan yang luas untuk mencukupi kehidupan sehari-hari. Masyarakat Seboto tidak hanya bekerja pada satu lahan pertanian, tetapi mereka juga dapat bekerja di lahan milik orang lain. Hasil dari panennya dijual melalui pengepul yang datang dari Boyolali, bahkan dari luar Boyolali. Namun, tidak semua hasil yang didapat dijual, sebagian untuk dikonsumsi sendiri. Masyarakat juga masih saling meminjam uang, dimana aktivitasnya masih bersifat kekeluargaan tidak semua masyarakat Seboto memiliki lahan untuk bertani, sehingga ada yang bekerja sebagai buruh kesana kemari dengan sistem pekerjaan borongan. Adanya pengembangan ekonomi kreatif yaitu pengenbangan kegiatan ekonomi berdasarkan pada kreativitas, keterampilan dan bakat individu untuk menciptakan daya kreasi dan daya cipta individu yang bernilai ekonomis dan mensejahterakan masyarakat, dengan tujuan ekonomi kreatif tidak hanya terkait dengan penciptaan nilai tambah secara ekonomi , tetapi juga menambah nilai secara sosial, budaya dan lingkungan yang terwujud dalam bentuk karya tari yaitu Tari Angguk Rodat.

\section{SIMPULAN}

Tari Angguk Rodat merupakan tari yang bernafaskan Islami yang hidup dan berkembang di Desa Seboto Kecamatan Ampel Kabupaten Boyolali yang memadukan unsur gerak, musik, dan sholawat. Tari Angguk Rodat sudah ada di Desa Seboto sejak tahun 1911.

Pertunjukan Tari Angguk Rodat sebagai identitas budaya masyarakat memiliki urutan: 1) ayun-ayun kipas; 2) laku nundhuk; 3) lompat ayun kipas; 4) laku telu; 5) laku nundhuk (2); 6) laku telu(2); 7) ayun-ayun kipas (2); 8) langkah ayun kipas; 9) angguk-angguk; 10) muslaku mundur; 11) langkah ayun kipas (2). Tema Tari Angguk Rodat yaitu keagamaan dan perjuangan. Alat musik 
Tari Angguk Rodat yaitu bedug, terbangan, saron, demung, bende, drume, bass drume, floor drume, gitar melody, dan keyboard.

Identitas budaya melalui Tari Angguk Rodat tercermin dalam iringan, tata rias dan busana, pola lantai, properti yang menggambarkan sebuah kebiasaan dari masyarakat Seboto dan seringnya tarian ini diikutkan dalam acara-acara penting di Kabupaten Boyolali, sehingga menimbulkan tarian ini menjadi salah satu identitas budaya di Desa Seboto. Identitas budaya melalui Desa Seboto dapat dilihat melalui biologis, sosial, kultural, religious dan ekonomi.

Pandangan peneliti terhadap bentuk pertunjukan Tari Angguk Rodat sebagai identitas masyarakat Sebotoke kedepannya mungkin akan berubah, karena adanya perubahan perilaku masyarakat yang disebabkan oleh perkembanganzaman.

Saran untuk masyarakat agar tetap melestarikan Tari Angguk Rodat sebagai identitas sekaligus warisan budaya di Desa Seboto. Saran untuk Paguyuban Suko Budoyo melakukan regenerasi agar kesenian Tari Angguk Rodat tidak punah.

\section{DAFTAR PUSTAKA}

Petersen Roice, Anya. 2007. Antropologi Tari. Bandung: Sunan Ambu PREES STSI.

Endarswara, Suwardi. 2003. Metodologi Penelitian Kebudayaan. Yogyakarta: Gadjah Mada University Press.

Endarswara, Suwardi. 2012. Filsafat Sastra: Hakikat, metodologi dan teori. Yogyakarta: layar Kata.

Ibrahim MA. 2015. Metodologi Penelitian Kualitatif. Bandung: Alfabeta.

Jazuli, M. 2008. Pendidikan Seni Budaya Suplemen Pembelajaran Seni Tari. Semarang: UNNES Press.

Mujianto, Yan. 2010. Pengantar Ilmu Budaya. Yogyakarta: Pelangi Publishing.
Sindara, Rytma. 2013. Tari Kretek Sebagai Tari Identitas Budaya Kabupaten Kudus Jawa Tengah. Sripsi. Universitas Negeri Yogyakarta. Yogyakarta.

Rohidi, Tjetjep Rohendi. 2011. Metode Penelitian Seni. Semarang: Citra Prima Nusantara.

Simatupang, Lono. 2013. Pergelaran Sebuah Mozaik Penelitian SeniBudaya. Yogyakarta: Jalasutra.

Sugiyino. 2009. Metode Penelitian Kuantitatif dan Kualitatif. Bandung: Alfabeta.

Sugiyono. 2014. Metode Penelitian Pendidikan Pendekatan Kualitatif, kuantitatif, dan RD. Bandung: Alfabeta. 